\title{
The adaptive life cycle of entrepreneurial ecosystems: the biotechnology cluster
}

\author{
Philip E. Auerswald • Lokesh Dani
}

Accepted: 27 March 2017 /Published online: 22 May 2017

(C) Springer Science+Business Media New York 2017

\begin{abstract}
We propose an empirical framework for assessing the vibrancy and trajectory of regional entrepreneurial ecosystems. We apply this framework to study the US National Capital Region's localized cluster of biotechnology-related entrepreneurship by building our analysis around a set of indicators of ecosystem vitality proposed by Stangler and Bell-Masterson (2015). This application constitutes an initial attempt at mapping the dynamics of an industry cluster within the adaptive life cycle of a wider regional ecosystem. We find that the biotechnology cluster in the National Capital Region entered a "reorientation" stage in the early 2000s, building up stored energy, capital, and connectedness in non-research-oriented activities. An increasing regional presence of large biotech firms in the past 5 years, a highly active and diverse start-up sector, increasing merger and acquisition activity, and declines in regional public funding for medical and clinical trials all suggest a transition of entrepreneurial activity in the region from a dynamic driven by federal research spillovers to one increasingly driven by private sector actors.
\end{abstract}

P. E. Auerswald $(\bowtie) \cdot$ L. Dani

Schar School of Policy and Government, George Mason University, 3401 Fairfax Drive, Arlington, VA 22201, USA

e-mail: auerswald@gmu.edu

L. Dani

e-mail: 1dani@gmu.edu
Keywords Biotech · Clusters · Complexity · Dynamics · Economic geography $\cdot$ Entrepreneurship $\cdot$ Evolutionary economics $\cdot$ Entrepreneurial ecosystems

JEL classification $\mathrm{B} 41 \cdot \mathrm{B} 52 \cdot \mathrm{L} 26 \cdot \mathrm{L} 65 \cdot \mathrm{O} 3 \cdot \mathrm{O} 31$. $\mathrm{O} 32 \cdot \mathrm{O} 33 \cdot \mathrm{R} 00 \cdot \mathrm{R} 1 \cdot \mathrm{R} 11 \cdot \mathrm{R} 58$

\section{Introduction ${ }^{1}$}

Alfred Marshall's 1920 masterwork, Principles of Economics, contains two statements that jointly go a long way toward setting the context for a special issue of Small Business Economics on entrepreneurial ecosystems. The first is: "The Mecca of the economist lies in economic biology rather than in economic dynamics." ${ }^{2}$ The second is: "When an industry has ... chosen a locality for itself, it is likely to stay there long: so great are the advantages which people following the same skilled trade get from near neighborhood to one another. The mysteries of the trade become no mysteries; but are as it were in the air, and

\footnotetext{
${ }^{1}$ The first two paragraphs of the introduction are shared with (Auerswald and Dani 2017).

${ }^{2}$ He continued: "But biological conceptions are more complex than those of mechanics. A volume on Foundations must therefore give a relatively large place to mechanical analogies; and frequent use is made of the term 'equilibrium,' which suggests something of statical analogy" (Marshall 1920, p. 19). Inspired by these words of Marshall's and the work of other foundational figures in the field of economics who similarly perceived a fundamentally biological order in the evolution of the economy - most notably, Spencer (1857) — economists have for decades sought to represent the adaptive dynamics evident in economic ecosystems. The seminal work of Nelson and Winter (1982) helped to define the currently thriving field of evolutionary economics.
} 
children learn many of them unconsciously." 3 These two passages in Principles have helped to inspire two distinct literatures in economics: the first, a literature on evolutionary economics exploring "economic biology," and the second, a literature on the localization of economic activity in general, and of inventive activity in particular, exploring how economically-relevant ideas come to be "in the air" in specific places.

Economists have only recently begun to connect these distinct literatures by studying localized systems of production and innovation-initially as evolutionary "clusters" and, in last few years, as "entrepreneurial ecosystems" at the subnational, regional level. ${ }^{4}$ This relatively recent emergence of work on regional entrepreneurial ecosystems has been prompted equally by the advance of models and empirical methods to represent the adaptive evolution of ecosystems, ${ }^{5}$ a discontinuous increase in the volume and quality of data available to economic geographers, ${ }^{6}$ and strong interest among policymakers. $^{7}$

Terjesen et al. (2017) go further in setting the context both for the issue as a whole, and for our paper, by distinguishing the now well-established literature on regional economic clusters from the emergent literature on entrepreneurial ecosystems. Briefly, clusters and entrepreneurial ecosystems differ in two primary ways. First, where clusters are bounded by an industry, entrepreneurial ecosystems cut across industries. Second, where clusters focus on relationships among firms, ${ }^{8}$ entrepreneurial ecosystems focus on the environment surrounding entrepreneurs - with entrepreneurs and entrepreneurship clearly at the center. Thus, entrepreneurial ecosystems are both broader (in terms of industry

\footnotetext{
$\overline{3}$ Emphasizing the central role of invention and innovation in geographical localization, Marshall continues: "Good work is rightly appreciated, inventions and improvements in machinery, in processes and the general organization of the business have their merits promptly discussed: if one man starts a new idea, it is taken up by others and combined with suggestions of their own; and thus it becomes the source of further new ideas" (Marshall 1920, p. 225).

${ }^{4}$ Acs et al. (2014) introduce the related but distinct concept of a National Entrepreneurial Ecosystem (NEE).

${ }^{5}$ For example, Holling et al. (1995), Holling (2001), Holling et al. (2002), and Gavrilets (1999, 2004).

${ }^{6}$ For example, as represented in early efforts by Rosenthal and Strange (2001), Wallsten (2001), and Auerswald et al. (2007).

${ }^{7}$ Isenberg (2010a, 2010b). The first two paragraphs of this paper are shared with Auerswald and Dani (2017).

${ }^{8}$ Such relationships among existing firms take a variety of forms, both formal and informal, and encompass an array of functional domains from supply chain linkages, knowledge sharing, training, marketing, sales, and policy advocacy.
}

scope) and narrower (in terms of unit of analysis) than clusters. ${ }^{9}$

We employ the term "adaptive" in a very specific manner in this paper to refer to the capacity of regional economic ecosystems to reconfigure assets to highervalued uses. Consistent with the usage in Weitzman (1970a), we consider adaptability in an economic ecosystem to be the formal equivalent of the elasticity of substitution in an aggregate (regional) production function. ${ }^{10}$ Entrepreneurship is a primary function activity within a regional economic ecosystem enabling such reconfiguration of assets to occur. For that reason, the study of adaptability in a regional context naturally focuses on the entrepreneurial ecosystem, which is a subset (and nested within) the broader regional economic ecosystem.

We do three things in the paper. First, we combine an ecological framework derived from Holling (2001) and modified in Martin and Sunley (2011) with a set of indicators for ecosystem dynamism introduced by Stangler and Bell-Masterson (2015) in order to describe stages in the life cycle of an industry cluster embedded within a regional entrepreneurial ecosystem. We distinguish between an economic ecosystem and an industrial cluster, as an ecologist would between an ecosystem and a resident species, or taxa of species. We argue that while clusters of industries and ecosystems are both geographically bounded with the properties to scale to different levels of agglomeration, a regional entrepreneurial ecosystem is best understood as being comprised of various clusters made interdependent by the fact that they share the same geographical space. Consequently, clusters coevolve with related clusters in the same ecosystem. This can explain why similar clusters in different regions may evolve differently. Entrepreneurial ecosystems consist of the higher-order complex of social, cultural, political, and economic feedback mechanisms

\footnotetext{
${ }^{9}$ In Auerswald and Dani (2017), we offer a broader framework of the "economic ecosystems" within which both clusters and entrepreneurial ecosystems naturally fit. The fundamental unit of analysis in that paper, as in Auerswald et al. (2000), Auerswald (2007), and Auerswald (2017), is the firm-level production process, or "production algorithm." We argue in those related papers that the production algorithm in economic ecosystems is directly analogous to DNA in biological ecosystems; in turn, the creation of a new industry in economic ecosystems is analogous to speciation in biological ecosystems. In the interest of space, we do not develop that dimension of the theory in this paper.

${ }^{10}$ See also Auerswald (2007), Auerswald (2012, pp. 101-103), and Acs, Autio, and Szerb (2014).
} 
within which the adaptive life cycle of any particular industrial cluster is embedded.

Second, we operationalize theory into practice by applying metrics to the case of the evolution of the biotechnology (biotech) cluster in the Washington, D.C.-Baltimore Combined Metropolitan Statistical Area (the National Capital Region). We discuss the evolution of the biotechnology cluster in the National Capital Region across different phases of its life cycle with an attention to processes within the region's entrepreneurial ecosystem that have been at least partially determinative of the cluster's evolutionary pathway. In so doing, we advance a practical application of entrepreneurial ecosystem analysis that is both grounded in the theory of evolutionary economics (Nelson and Winter 1982) and informed by ecological theories of life cycle dynamics in natural and social systems (Bengtsson, Nilsson, Franc, and Menozzidi 2000; Holling and Gunderson 2002). In so doing, we distinguish a dominant view of the cluster life cycle from our "adaptive life cycle" approach, highlighting cluster coevolution, speciation, and path-dependence as salient factors in the mechanics of entrepreneurial ecosystem.

Third, we propose that the framework used in the analysis is a replicable one, based on case sampling, that can be generalized to study the dynamics of various types of agglomerations in the context of their regional economies and to inform policy accordingly. Cluster analysis has become a cornerstone of regional analysis and is widely used to study how regional economic advantage agglomerates across different dimensions of economic activity. Where applied dynamically, it has proved useful in studying the life cycles of products, technologies, as well as industries. Nonetheless, a notable limitation has been in its inability to account sufficiently for the heterogeneous growth trajectories of the same cluster across different regions over the same time periods (Martin and Sunley 2011). By adopting an ecosystem approach, it becomes possible to account for this heterogeneity by addressing region-specific dynamics. To capture this, our method is primarily descriptive and makes use of a broad range of publicly available data sources. As ecosystem processes are numerous and comprised of complex simultaneous interactions, it becomes necessary to identify "controlling processes" (Holling 2001) - ecosystem indicators that govern the dynamics of the system as a whole. We apply the entrepreneurial ecosystem indicators suggested by Stangler and Bell-Masterson (2015) to the example of the
National Capital Region's biotech cluster in the framework of the adaptive life cycle of entrepreneurial ecosystems (Holling 2001). Our intention is to advance the theory of industry life cycles by situating cluster dynamics within the larger context of the evolution of the regional entrepreneurial ecosystem.

The organization of the paper is as follows. In Section 2, we set forth the conceptual framework derived from ecology and evolutionary biology. In Section 3, we describe the role of entrepreneurship in economic ecosystems, distinguishing entrepreneurial ecosystems from industrial clusters. We also describe how we propose to use the adaptive life cycle model to represent the dynamics of individual clusters within an entrepreneurial ecosystem, with "density," "fluidity," "connectivity," and "diversity" functioning as indicators of the vibrancy of the entrepreneurial ecosystem in relation to its life cycle stage. In Section 4, we detail our methodology of case sampling, including our selection criteria of metrics for each indicator. In Section 5, we apply our theory to empirical data on the National Capital Region's biotechnology cluster and evaluate each of the metrics in terms of their contribution to the four entrepreneurial ecosystem indicators. Our discussion in Section 5 focuses on the adaptive life cycle of the National Capital Region's biotech cluster in the context of both national (biotech industry) and regional (business cycle) trends. In Section 6, we summarize our findings, highlighting the value and potential limitations of the approach we have taken - mapping entrepreneurial ecosystem indicators onto the adaptive life cycle of a regional industry cluster with the intent of informing public policy.

\section{Conceptual framework}

\subsection{Entrepreneurial ecosystems}

Business and public policy practitioners have employed the term "entrepreneurial ecosystem" for some time to convey the importance of interrelated networks of individuals, institutions, and their organizations in shaping opportunity for new business formation (Valdez 1988). The application of the term has gained momentum in recent years as the entrepreneurship literature has itself evolved beyond a consideration of the personal characteristics that drive individual entrepreneurs, to a view that incorporates the external environmental factors as a 
facilitative source of entrepreneurial opportunity. For instance, Van De Ven (1993) argued that the study of entrepreneurship should move beyond an exclusive analysis of the characteristics of individual entrepreneurs to consider also the social, political, and economic factors that influence entrepreneurship. He identified industrial infrastructure such as regulations and standards for new technologies, public investments in research and development of basic science, financial markets, availability of qualified human capital, and institutional options that allow for the commercialization of knowledge, as essential entrepreneurial infrastructure that enables individual entrepreneurs to successfully take innovations to market.

Entrepreneurship is inherently a risky activity that turns inventions into innovations ${ }^{11}$ and relies on a network of institutional and individual investors that provide financial and organizational capital to enable new enterprise. Auerswald and Branscomb (2003) termed this gap between the technical invention and the business enterprise as the "Darwinian Sea", calling forth the image of entrepreneurs overcoming unpredictable challenges in a chaotic environment in the effort to realize success. They identified at least four of these challenges to be (1) differing motivations for research; (2) disjuncture between technologist and business manager; (3) sources of financing; and (4) enabling infrastructure, thus highlighting the complex interactions inherent in the internal and external dynamics of the entrepreneurial process (Branscomb and Auerswald 2001; Auerswald and Branscomb 2003). We propose that a healthy entrepreneurial ecosystem lowers such barriers to bringing inventions to market by fostering fluid networks of collaboration across agents of entrepreneurial change.

Yet, entrepreneurial ecosystems are evolutionary. The evolution of an entrepreneurial ecosystem has a determinative impact of the adaptive life cycles of industry clusters embedded within the ecosystem. The emergence of a new regional cluster requires not only strong innovative prerequisites, such as knowledge, skill, and technical capabilities, but also stochastic

\footnotetext{
${ }^{11}$ Schumpeter referred to the "new combination of means of production" as the "fundamental phenomenon of economic development" (Schumpeter 1951, p. 74) and placed innovation in the middle of invention and imitation in bringing about technical change. He noted that innovation brought inventions to the market that would then diffuse as a result of firms imitating the new technology. It is because of this role in introducing novelty to the market that Schumpeter (1951) positioned entrepreneurs as the key drivers of economic growth.
}

events that result in the speciation of new economic activity, facilitated by the coevolution of innovation networks that foster entrepreneurial outcomes. Accordingly, and similar in spirit to Martin and Sunley's (2011) conceptualization of cluster life cycles, our discussion on entrepreneurial ecosystems focuses on the feedback mechanisms and self-reinforcing interactions within complex systems that characterize emergence and selforganization of economic activity. We emphasize a system-of-systems view of transition dynamics within the multi-level perspective (Genus and Coles 2008) as a means to contextualize the adaptive life cycle of individual entrepreneurial ecosystems and the evolution of regional industry clusters. This emphasis provides us with a means to distinguish between the traditional view of clusters and a biologically- informed evolutionary view of entrepreneurial ecosystems, the latter focusing on networks and linkages in the system that boost entrepreneurship.

\subsection{The adaptive life cycle of entrepreneurial ecosystems}

As Fig. 1 illustrates, the ecosystem adaptive cycle alternates between short periods of systemic restructuring triggered by a disturbance (release and reorganization), followed by longer periods of accumulation and transformation of resources (exploitation and conservation). The development of the ecosystem from the exploitation phase to the conservation phase captures the traditional notions of ecological succession. Organisms rapidly

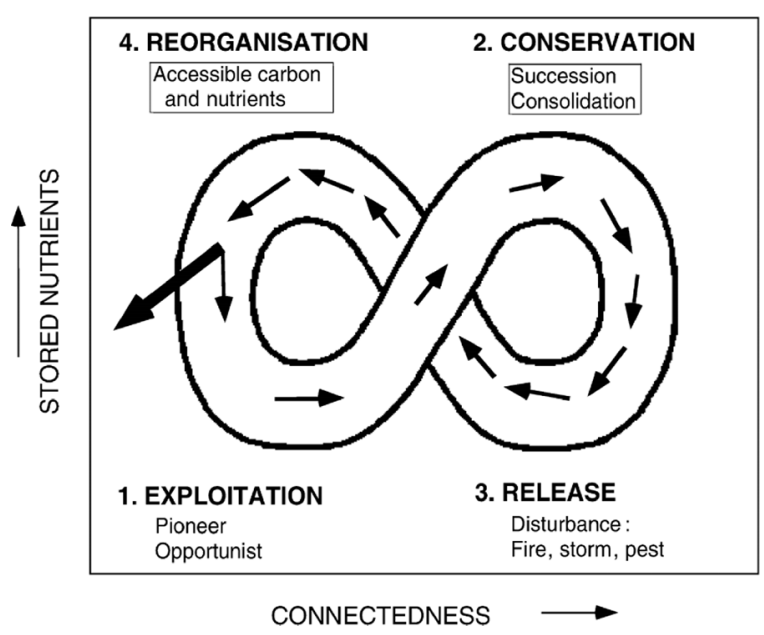

Fig. 1 Succession and reorganization of ecosystems. Source: Bengtsson, Nilsson, Franc, and Menozzidi (2000) 
colonize a disturbed space to accumulate stores of energy and form complex interdependencies. The shorter period beginning with the release is often referred to as the phase of "creative destruction" to parallel Schumpeterian entrepreneurship (Holling 2001). It occurs when the over-connected dependencies resulting from the conservation phase collapse under some external disturbance, such as a fire or disease. The result is a release of a great amount of stored energy, potentially creating new opportunity for more complex reorganization with more diverse inputs.

These features are paralleled in economic ecosystems as well and can be observed in the entrepreneurial activity that drives change in the structure of the ecosystem. Specifically, we can consider the exploitation phase to be crowded by new business activity that is working and defining a new space of opportunity. Pioneers and opportunists who have preferential access to the newly released energy and resources will be the first to jump to entrepreneurial action and the overall diversity of the cluster will increase. As the system matures into the conservation phase, consolidation across firms will establish new system-level standards that in turn enable more specialized innovative activity. The structure of the ecosystem will have become denser and more interconnected across different scales of economic activity. As the networks become denser and more embedded, the structure of the ecosystem becomes more rigid and consequently more vulnerable to large-scale disturbances. In certain configurations, a strong stochastic shock, such as a regulatory change, can significantly disentangle many networks of the structure and release abundant energy into the environment. ${ }^{12}$ Entrepreneurs will once again seek opportunity in this disturbance and begin to establish a new order to the ecosystem in the reorganization phase.

\section{Contextualization}

In this paper, we are also concerned with the application of the adaptive life cycle model of ecosystems to cluster evolution. However, our focus is on the ecosystem resources and processes that are central to entrepreneurial opportunity and growth. Thus, we study the phase

\footnotetext{
${ }^{12}$ Stochastic events may affect ecological niches differently in an ecosystem (Holling 2001). Similarly, a large disturbance to an entrepreneurial ecosystem may lead to collapse of some entrepreneurial niches over others.
}

shift characteristics of the adaptive life cycle in terms of our indicators and interpretively map them to ecosystem life cycle model of Bengtsson et al. (2000). Later, we discuss it in more detail in the context of the modified adaptive life cycle model of Martin and Sunley (2011).

Phase-state characteristics are represented as distinct in this typology; however, ecosystems are dynamic and constantly adapting their structures. Thus, when extending the analogy of the life cycle, it is relevant to speak of ecosystem transitions with a sense of the direction of ecosystem adaptation. Here, we briefly consider the back-loop and the fore-loop of the adaptive cycle in terms of the ecosystem shifting first from the "Release to Reorganization," and then from the "Exploitation to Conservation" phases.

\subsection{Release to reorganization}

Release refers to the opportunity that fuels the creative destruction phase. Resulting from some external disturbance, the tightly knit connected structures of the ecosystem come undone and large amounts of stored capital and energy are released within the ecosystem. This initiates the undoing of old established networks from the prior period of succession. Networks established during the shift from exploitation to conservation mature over a long period of time; however, the structural shift from release to reorganization occurs over a much shorter time scale and is very disruptive. Although established networks deteriorate and the interconnectedness of the ecosystem declines, reorganization sets the stage for a new rapid phase of exploitation and entrepreneurial opportunity followed by a long period of innovation and economic succession. The steady growth of the ecosystem, represented in Fig. 2, conceals the complex dynamics that underlie that growth.

\subsection{Exploitation to conservation}

Exploitation refers to the colonization of disturbed ecosystems where species capture easily accessible resources. It is the beginning of establishing order within a chaotic system. The conservation phase, on the other hand, is the "climax" phase of succession where stored nutrients and energy are at their peak and the system has achieved a high level of interconnectedness. It is a result of a long period of growth and reordering in the system and refers to the phase of the adaptive cycle when the 


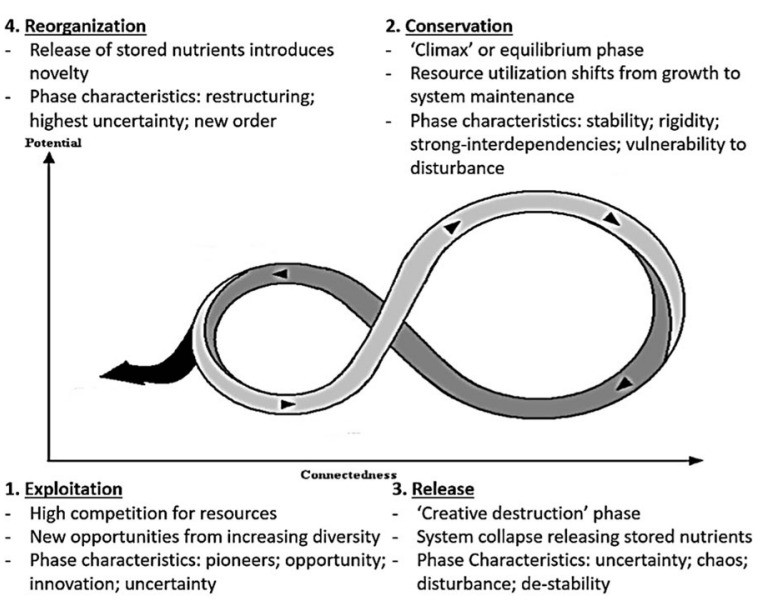

Fig. 2 Phase characteristics of the entrepreneurial ecosystem. Source: adaptation of Bengtsson, Nilsson, Franc, and Menozzidi (2000)

ecosystem has developed strong and complex interdependencies.

\section{Data and methodology}

\subsection{Data collection}

We used the National Capital Region's biotechnology cluster as an illustrative case study of the adaptive life cycle of the entrepreneurial ecosystem that has fostered the cluster regionally. Our purpose is to develop an empirical framework that assesses the entrepreneurial ecosystem's vitality and vibrancy with sufficient abstraction to allow for application to policy. With this view in mind, the metrics we selected for each indicator satisfy two criteria: practical criteria based on relevance of the metrics to the regional biotechnology ecosystem as well as the availability of sources and the theoretical criteria relating to each of the four indicators of ecosystem vitality. Another concern relating to studying biotechnology is empirically defining the biotechnology cluster. What is biotechnology, and how can it be measured?

Biotechnology loosely refers to all technology based on biology and includes products in agriculture, healthcare, genetic research, and environmental technology. Based on patterns of regulation, financing, and innovation, biotech products are most often categorized in practice under one of three industry sectors: biologics and drugs; biotech seeds and crops; and industrial biotech products such as biofuels, biomaterials, and biochemicals. However, there are many difficulties in categorizing firms in these groups, in particular since large firms are often active in all these related fields. Consequently, there is no official definition of the biotechnology sector.

To address this limitation, we use a North American Industry Classification System (NAICS)-based approach, similar to Hecker's (2005) method for classifying the hightechnology sector. We characterize biotechnology industries as having a high proportion of workers in biotechnology occupations, in turn defined as those occupations with a high proportion of workers who have attained advanced degrees in biotechnology fields. The compiled lists of biotechnology field of degree, occupation codes, and industry codes are provided in the Appendix. We also provide a list of patent classes that were qualitatively assessed as biotechnology related.

A limitation of this approach is that we focus on highskilled biotechnology occupations. Low- and middleskilled biotech occupations such as inspectors, testers, sorters, samplers, and weighers (SOC 51-9061) are not included in our classification. However, since the biotechnology sector is a high-technology sector employing a relatively larger share of scientists and workers with advanced degrees, we find this classification is appropriate for our purposes of studying the vitality of innovation in regional biotech entrepreneurial ecosystems.

An advantage of our approach is that we apply a classification of biotechnology activity that maps across fields of study, occupations, and industries. Thus, we can compile data from various sources into individual indicators of entrepreneurial ecosystem vitality. We provide a complete list of our data sources for each indicator in the Appendix.

\subsection{The theoretical criteria}

We empirically define an entrepreneurial ecosystem to differ from clusters in that they are not bounded by an industry but cut across one-dimensional classifications of industry interactions. Where clusters focus on relationships among firms, ${ }^{13}$ entrepreneurial ecosystems focus on the environment surrounding entrepreneurs.

\footnotetext{
${ }^{13}$ Such relationships among existing firms take a variety of forms, both formal and informal, and encompass an array of functional domains from supply chain linkages, knowledge sharing, training, marketing, sales, and policy advocacy.
} 
Geography is an essential basis for the empirical definition, but the focus of analysis is on the environmental conditions and network of interactions that facilitate new business growth within the economic ecosystem. As these processes are varied and complex, we offer four ecosystem indicators that reflect the "controlling processes," or the driving mechanisms that provide the environmental conditions to produce better entrepreneurial outcomes.

\subsection{Ecosystem indicators}

\subsubsection{Density - agglomeration externalities}

Density refers to the sheer concentration of economic agents and activity that bolsters agglomeration externalities for the sector. As the biotechnology sector is a highskilled sector, we expect agglomeration externalities to be greatest for returns to investments in human, knowledge, and financial capital. Accordingly, we measure entrepreneurial ecosystem density in terms of concentrations of entrepreneurs and managers, research and development $(\mathrm{R} \& \mathrm{D})$ workers, and patenting activity. We compare the estimates to the national average to identify competitive advantages and as a basis for comparison to other ecosystems. In terms of knowledge capital, we indirectly estimate the change in funds allocated in regional biotechnology activities as a proxy for the growth in the ecosystem's stock of knowledge (Table 1).

\subsubsection{Fluidity - elasticity of substitution among factors}

Fluidity in the entrepreneurial ecosystem indicates where ecosystem resources are being allocated toward the most productive activities. The expectation of optimal resource allocation is that early-stage ecosystems devote greater resources to capacity expansion and infrastructure, while more developed ecosystems allocate resources to activities that utilize established infrastructures for immediate gains in output.

In this respect, as markets develop better institutional frameworks, they allow for more fluid substitutions between labor and capital, thus enabling greater technical change (Weitzman 1970a). Specifically, in a stylized model of development, Weitzman (1970b) distinguished between direct $(\alpha)$ capital that contributes immediately to productive activity, such as labor, and an institutional $(\beta)$ capital that provides the infrastructure that enables the productive capacity of the direct capital. In early stages of development, infrastructure development is more critical and provides the early capacity for building economies of scale, while for a mature economy, returns to direct capital investments are greater.

Our empirical indicator thus assesses the fluidity of labor and capital into the ecosystem, as well as where the allocation of knowledge resources is directed. For this purpose, we assess the net migration rates of workers in the biotechnology sector, the job turnover of R\&D services, the number of high-growth firms, and their average growth rates. We also collect data on the allocation of resources between basic and applied research, and product development (Table 2).

\subsubsection{Connectivity — absorptive capacity}

When aligned, interactions among institutional structures and actors create increasing returns to entrepreneurship. Thus, as entrepreneurial ecosystems mature, they become more networked, increasing both their absorptive capacity and their rigidity to change. In our

Table 1 Density indicator for entrepreneurial ecosystems

\begin{tabular}{lll}
\hline Indicator & Biotechnology cluster metrics & Source \\
\hline Density & Percent self-employed with biotech degree & ACS 2013 5-year estimates \\
& Percent managers with biotech degree & ACS 2013 5-year estimates \\
& Regional share of US biotech patents 2000-2013 & USPTO database \\
& Biotech venture capital national ranking & fiercebiotech.com \\
& Research personnel funded in 2013 & National Science Foundation \\
& $\%$ change PIs funded 2010-2013 & National Science Foundation \\
& $\%$ change post-docs funded 2010-2013 & National Science Foundation \\
\hline
\end{tabular}


Table 2 Fluidity indicator for entrepreneurial ecosystems

\begin{tabular}{|c|c|c|}
\hline Indicator & Biotechnology cluster metrics & Source \\
\hline \multirow[t]{8}{*}{ Fluidity } & $\begin{array}{l}\text { Biotech population flux (net } \\
\text { migration) }\end{array}$ & $\begin{array}{l}\text { ACS } 2013 \text { 5-year } \\
\text { estimates }\end{array}$ \\
\hline & In-migration of biotech workers & $\begin{array}{l}\text { ACS } 2013 \text { 5-year } \\
\text { estimates }\end{array}$ \\
\hline & $\begin{array}{l}\text { Job turnover in scientific R\&D } \\
\text { services in } 2013\end{array}$ & $\begin{array}{l}\text { Quarterly workforce } \\
\text { indicators }\end{array}$ \\
\hline & $\begin{array}{l}\text { Share of funding for basic } \\
\text { research }\end{array}$ & $\begin{array}{l}\text { National Science } \\
\text { Foundation }\end{array}$ \\
\hline & $\begin{array}{l}\text { Share of funding for applied } \\
\text { research }\end{array}$ & $\begin{array}{l}\text { National Science } \\
\text { Foundation }\end{array}$ \\
\hline & $\begin{array}{l}\text { Share of funding for } \\
\text { development }\end{array}$ & $\begin{array}{l}\text { National Science } \\
\text { Foundation }\end{array}$ \\
\hline & Number of high-growth firms & Inc. 50002015 \\
\hline & $\begin{array}{l}\text { Average growth rate of Inc. } 5000 \\
\text { firms in health }\end{array}$ & Inc. 50002015 \\
\hline
\end{tabular}

connectivity indicator, we are interested in assessing entrepreneurial networks that emphasize the interconnections between agents and institutions that enable entrepreneurial opportunism. For this purpose, we assess ecosystem connectivity along three dimensions: the strength of the connections, evaluated in terms of concentration of total R\&D funding, and its sources; the direction of the connections, evaluated in terms of which subsectors are driving innovation in the ecosystem; and the vitality of the social networks surrounding the entrepreneurial agents, assessed in terms of star scientists and the presence of biotechnology incubators (Table 3).

\subsubsection{Diversity - decreasing returns to given factors; combinatorial growth}

The rate of production of new knowledge using the current stock of available knowledge is a key determinant of entrepreneurial growth. Weitzman (1998) presents a model of long-term growth based upon a production function that utilizes new configurations of old ideas as an input to produce new knowledge. His main result is to show that the upper limit for long-term growth is the recombinant capacity in the current stock of knowledge. A greater diversity of ideas thus permits combinatorial growth limited only by how well these ideas fit with one another.

Consequently, our diversity indicator captures heterogeneity in ideas and knowledge as represented by
Table 3 Connectivity indicator for entrepreneurial ecosystems

\begin{tabular}{lcc}
\hline Indicator & Biotechnology cluster metrics & Source \\
\hline Connectivity & Total R\&D federal funding & National Science \\
& Fo10-2013 & Foundation \\
R\&D university funding 2013 & National Science \\
& Foundation \\
\% change foreign funding & National Science \\
2010-2013 & Foundation \\
$\%$ change medical and clinical & National Science \\
trial funding 2010-2013 & Foundation \\
$\%$ change in biomed and life-sci & National Science \\
funds 2010-2013 & Foundation \\
Star scientists & Web of Science \\
Capital region share of US & Web of Science \\
biotech researchers & \\
Biotech incubators & GEN, Biospace, \\
& FierceBiotech \\
\hline
\end{tabular}

the ecosystem's workforce and industry composition. We focus on the share of women and immigrant entrepreneurs in the biotech ecosystem, as they are proxies for labor force diversity. We also consider the sectoral concentration of the ecosystem, with the expectation that more specialized sectors employ less variety of production processes within the ecosystem, reducing the potential for recombinant growth (Table 4).

\subsection{Data analysis}

The data analysis maps each of the ecosystem indicators to the adaptive life cycle of ecosystem development. As discussed previously, the biological adaptive cycle alternates between short periods of systemic restructuring triggered by a disturbance (release and reorganization), followed by longer periods of accumulation and transformation of resources (exploitation and conservation).

Table 4 Diversity indicator for entrepreneurial ecosystems

\begin{tabular}{lll}
\hline Indicator & Biotechnology cluster metrics & Source \\
\hline Diversity & $\begin{array}{c}\text { Percent women self-employed in } \\
\text { biotech }\end{array}$ & $\begin{array}{c}\text { ACS } 2013 \text { 5-year } \\
\text { estimates }\end{array}$ \\
$\begin{array}{c}\text { Percent immigrants self- } \\
\text { employed in biotech }\end{array}$ & ACS 2013 5-year \\
Immigrant share of biotech & estimates \\
workforce & ACS 2013 5-year \\
Employment share of the largest & County Business \\
NAICS in cluster & Patterns 2013 \\
\hline
\end{tabular}


The development of the ecosystem from the exploitation phase to conservation captures the traditional notions of ecological succession. Organisms rapidly colonize a disturbed space to accumulate stores of energy and form complex interdependencies. The shorter period beginning with the release is often referred to as the phase of "creative destruction" to parallel Schumpeterian entrepreneurship (Holling 2001). It occurs when the overconnected dependencies resulting from the conservation phase collapse under some external disturbance, such as a fire or disease. The result is a release of a great amount of stored energy, potentially creating new opportunity for more complex reorganization with more diverse inputs.

In the same vein, Martin and Sunley (2011) argue that whereas a classic industry or cluster life cycle model follows the linear progression through birth, growth, maturity, decline, and death, empirical evidence of the life cycle of industrial clusters depicts a diverse progression that is non-linear, in many cases recursive. Actual industrial cluster life cycles are thus better represented by the evolutionary dynamics of complex adaptive systems, similar in essence to the adaptive life cycle model developed by Holling and Gunderson (2002), but modified to be less "lumpy," which is to say, capable of short-term recursive loops during a cluster's growth stage or its stabilization stage (Fig. 3).

A key feature of the modified model is that it allows for multiple additional trajectories that clusters may take depending on their specific histories. For instance, in the Constant Cluster Mutation cycle, high rates of entrepreneurial activity may keep the sector highly diversified and conditions may persist that are unfavorable to the consolidation in the cluster. In the Cluster Stabilization cycle, the

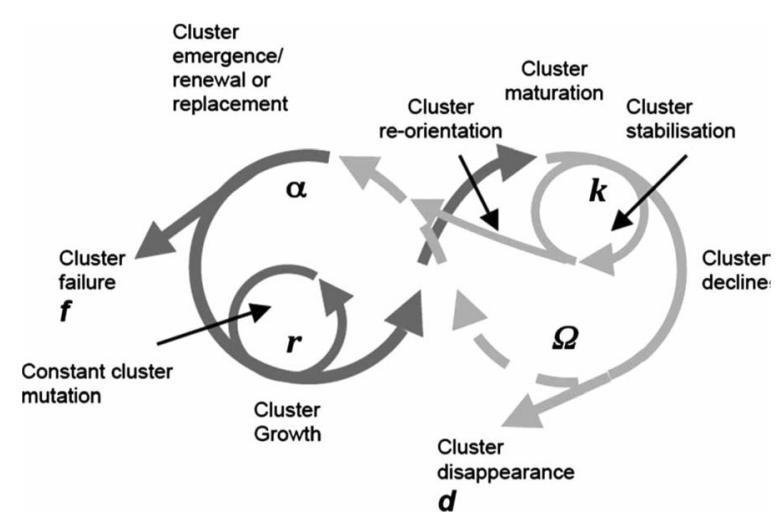

Fig. 3 The modified cluster cycle model. Source: Martin and Sunley (2011) cluster may achieve a relatively stable state where the industrial mix of the cluster does not change over long periods. The Cluster Reorientation phase allows for mature clusters to reorient their focus toward new technologies or capabilities. The Cluster Failure and Disappearance cycles allow pathways for cluster exit, either early in the adaptive cycle or where all the cluster capabilities are eliminated.

\section{Results and discussion}

\subsection{Biotechnology in the USA: the national context}

The USA has the largest biotechnology sector by revenue in the world and this sector is strongly integrated into the national economy. By some estimates, biotechnology contributed over $\$ 324$ billion or more than $2 \%$ of GDP in 2012 (Carlson 2016). It has also seen annual revenue gains over $10 \%$ for the past decade, making it the fastest growing sector in the country, and even during the recessionary years of 2007 to 2012, the national biotechnology revenue growth was greater than $5 \%$ of annual US GDP growth (Carlson 2016).

A unique feature of biotechnology in the USA is that it is the most R\&D intensive and capital focused in the world (Biotechnology Industry Organization 2012). It boasts considerable investments in intellectual property and consequently has developed within the context of competition laws and institutional structures, both formal and informal, facilitating innovation. The high concentration of capital alongside the need for continued innovation makes this sector a unique and interesting example to study entrepreneurial networks of innovation and the adaptive behavior of these networks in the life cycle of the industry.

Given this national framework of biotechnology as a fast-growing innovative and robust sector for economic growth, many subnational regions have pursued policies to encourage biotech in their own economies. However, not all regions have been equally successful in developing biotechnology sectors. For instance, Audretsch (2001) assessed the evolutionary dynamics of the sector and identified that both knowledge and financial capital concentrations resulted in the sector developing only in a handful of US regions. He also attributed entrepreneurial networks and technology transfer programs as crucial to developing the institutions supportive of regional agglomerations for biotech sector development. Cooke (2002), studying the 
networks of innovations in the biotechnology cluster of Cambridge, MA, and Cambridge, England, similarly argues that the regional development of the cluster required a convergence of both public and private initiatives that has facilitated the development of systemic features that prop up and enable the complex interactions required to regionally develop and sustain a biotech sector. Feldman et al. (2005) use the evolution of the biotechnology cluster in the US Capital Region as a study for how entrepreneurs through their enterprises play a critical role in cluster formation. Casper (2007) underscored the role of social networks across firms in the development of the biotech cluster in the San Diego area. The literature in this regard shows strong consensus for the role of complex adaptive systems of innovation that encompass both formal and informal institutions for the development of innovative clusters such as biotechnology.

We contribute to this literature by focusing on the adaptive dynamics of entrepreneurial ecosystems using a similar illustrative example of the biotechnology cluster in the National Capital Region of the USA.

\subsection{The National Capital Region's biotechnology cluster}

The National Capital Region is comprised of the Washington, D.C.-Baltimore Combined Metropolitan Statistical Area and ranks among the top 10 biotechnology clusters in the USA. Figure 4 below shows the geographical expansion of the biotechnology cluster in the National Capital Region from 1990 to 2015.

As of 2016, the National Capital Region employed nearly 56,000 workers in the biotechnology- and healthrelated activities, a concentration that is more than twice the national average. It remains one of the fastest growing regional sectors, increasing employment by $25 \%$ since 2003. Regional projections expect the sector to grow between a low of $5.4 \%$ and a high of $22.6 \%$ over the next decade (Fuller 2016).

Even as of 2013, the core of the biotech cluster ${ }^{14}$ in the National Capital Region boasted over 400 biotech establishments employing over 11,600 individuals. A significant $69 \%$ of these firms were small, employing less than

\footnotetext{
${ }^{14}$ We define the biotechnology cluster narrowly around NAICS classifications that are directly involved in biological or biomolecular production. This includes the production of pharmaceuticals and medicines as well as agriculture- and plant process-related chemicals. A complete list of the included NAICS sectors is provided in the Appendix.
}

10 workers, but they engaged in over a quarter of the region's private sector biotech $\mathrm{R} \& \mathrm{D}$ activity. The region is also home to five large biotech companies with global reach that employ over 500 workers each. ${ }^{15}$ Accordingly, the National Capital Region is considered a hotbed for biotech mergers and acquisitions (M\&A) and attracts significant venture capital to fuel its growth. In 2014 alone, this regional cluster attracted $\$ 319.65$ million in venture capital investments, earning it the fourth rank in the nation for biotech venture capital (VC) funding following only San Francisco, Boston, and San Diego, but beating out Oakland, Seattle, and even New York City (Fig. 5). ${ }^{16}$

The cluster's biotech competitive advantage, for the private sector, stems specifically from R\&D activity and from the manufacture of analytical laboratory instruments. The cluster lags the nation in almost all other NAICS categories. It is worth noting that NAICS categories are not comprehensive in accounting for all biotechnology-related activity in the region but are the most commonly used product-based categorization to study industry clusters.

The National Capital Region's biotech activity concentrates on the production of vaccines and immunotherapeutics, health-related information technologies, regenerative and personalized medicine, and biotech support services. ${ }^{17}$ Much of this regional concentration has derived as a result of generous federal funding. For instance, federal funding through the National Institutes of Health (NIH) supported mapping the first human genome in the early 1980s and consequently the region developed an early competitive advantage in biotech. Today, federal agencies such as DARPA and NIH support novel drug and vaccine development in light of global security threats and the region has grown to be a leader in vaccine and novel drug technologies. As such, because the biotech cluster in the WMA emerged in the shadow of the federal government, it has a unique entrepreneurial structure that is influenced by federally directed R\&D activity. This provides a unique competitive advantage that has consistently ranked the region among the top 5 in the nation for biotech-related activity. ${ }^{18}$

\footnotetext{
${ }^{15}$ Authors' estimates based on data from County Business Patterns.

${ }^{16}$ Report in the industry journal FierceBiotech: http://www. fiercebiotech.com/story/top-15-cities-biotech-venture-funding/201403-06

${ }^{17}$ Maryland Department of Commerce.

${ }^{18}$ Biotech industry journal GEN: http://www.genengnews.com/insightand-intelligence/top-10-u-s-biopharma-clusters/77900393/
} 


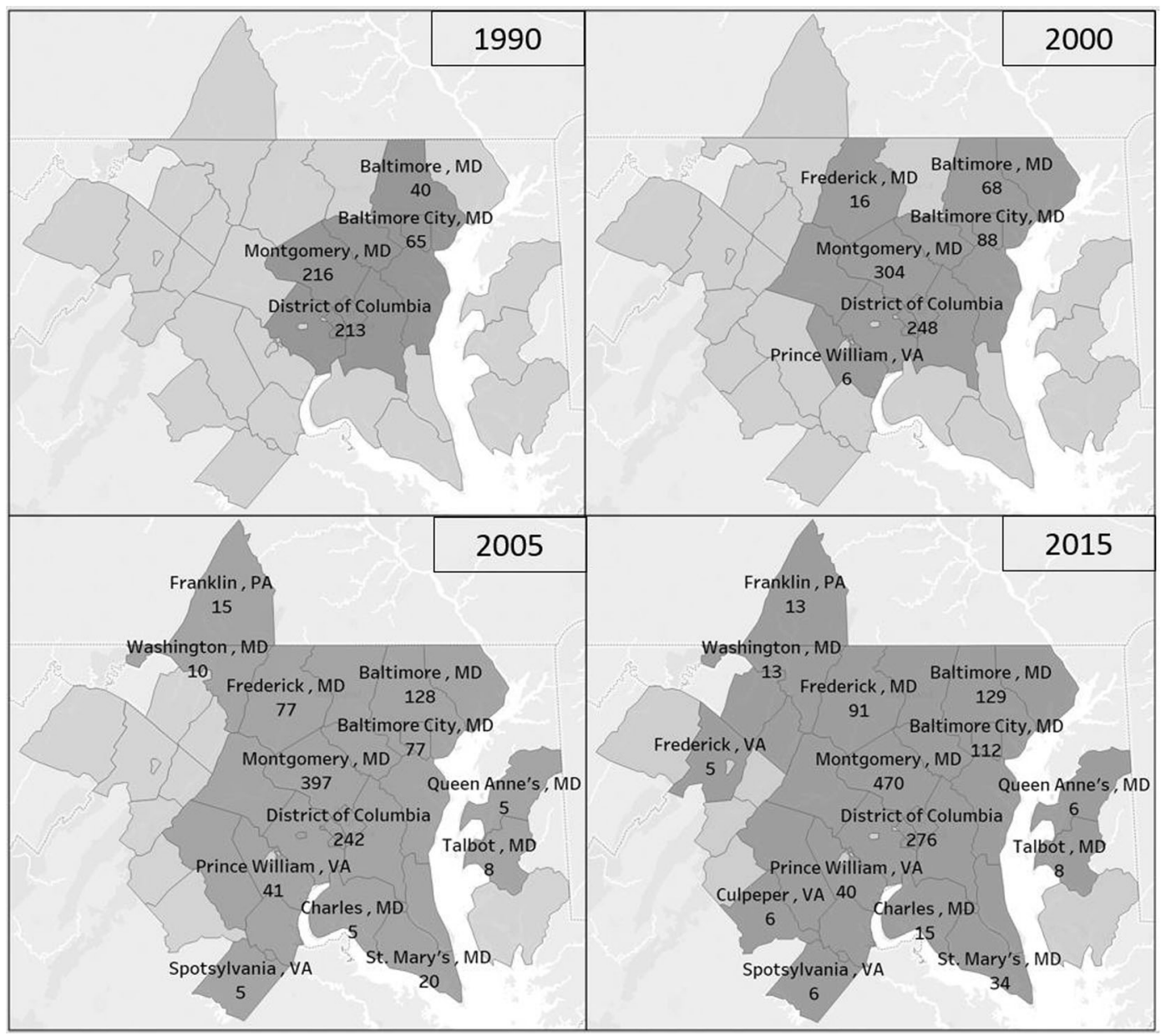

Fig. 4 The geographical expansion of the Capital Region biotech cluster 1990-2015. Shaded counties have at least five biotech establishments. Not all counties are labeled. Source: Quarterly Census of Employment and Wages 1990-2015

\subsection{Adaptive life cycle dynamics: speciation} of the biotechnology cluster

For the National Capital Region biotech cluster, the disturbance that triggered the release and reorganization arrived in the 1980s in the form of the Stevenson-Wydler Technology Innovation Act and the Bayh-Dole University and Small Business Patent Act (Feldman and Francis 2003). These laws were introduced to improve American competitiveness and eased restrictions on the transfer and licensing of publicly funded $R \& D$ to the private sector. Following this regulatory change, much of the biotech research that was performed by the federally funded research and development centers (FFRDCs) was now open to commercialization by regional entrepreneurs. Nutrients stored in the ecosystem in the form of advanced knowledge on genetic technologies were suddenly released into the system. This led to the early exploitation phase of the ecosystem's life cycle and the emergence of the regional biotech cluster (Fig. 6).

\subsection{Mapping indicators to the life cycle}

\subsubsection{Density—high and increasing}

The density of the National Capital Region's biotech entrepreneurial ecosystem is highly concentrated and continues to increase in its intensity. As the biotech cluster does not have a standardized definition based on the NAICS nor according to standard occupational 

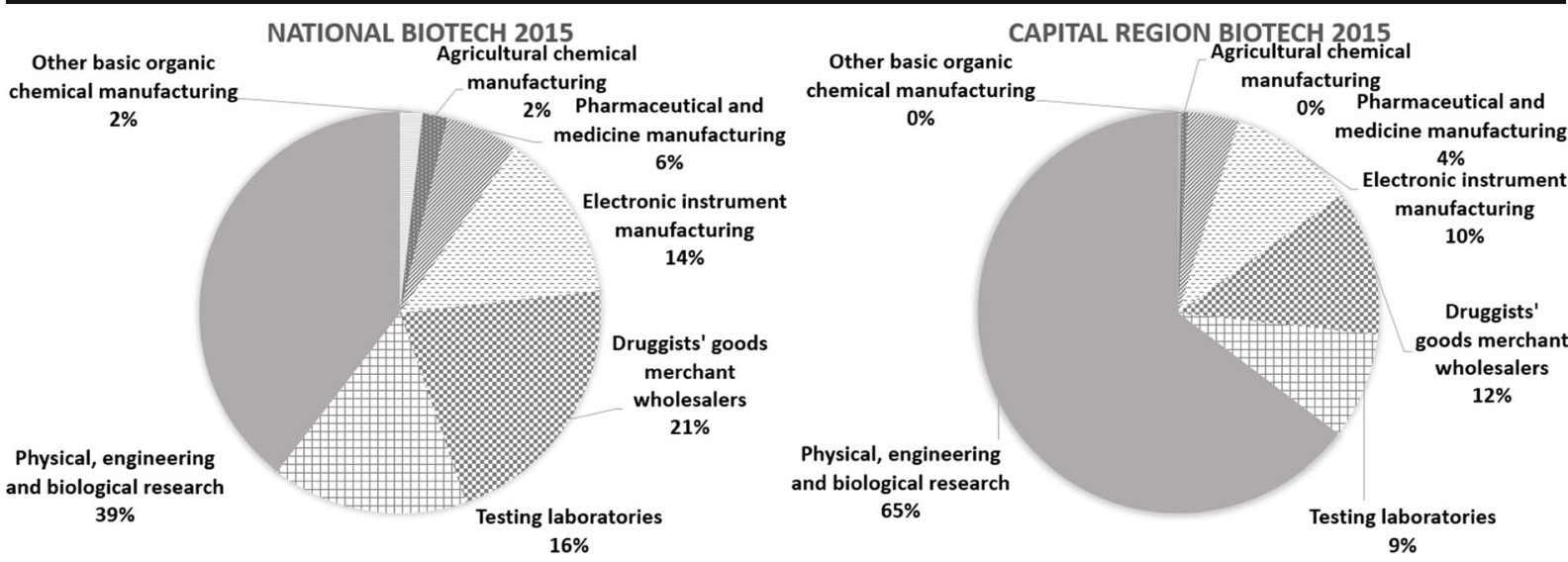

Fig. 5 Comparison of the National and Capital Region biotechnology clusters, 2015. Source: authors' estimates of QCEW 2015 establishment data

codes (SOC), we measure entrepreneurial activity in the cluster based on self-employment levels of individuals with advanced degrees in biotech-related fields. We compare these to the overall level of self-employment as well as with the national rates. As significant biotech employment in the National Capital Region cluster is undertaken in federal agencies, we also estimate the proportion of managers with a biotech degree in the cluster as compared to the nation. Table 1 below reports these estimates and tells us that the biotech cluster in the National Capital Region has higher self-employment rates and managers with biotech-related skills than the national average.

However, an entrepreneurial ecosystem relies not only on start-up talent but also on the intensity of regional innovative activity and the capital resources needed to bring inventions to market, viz., venture capital funding. In Table 1, we also report the cluster's share

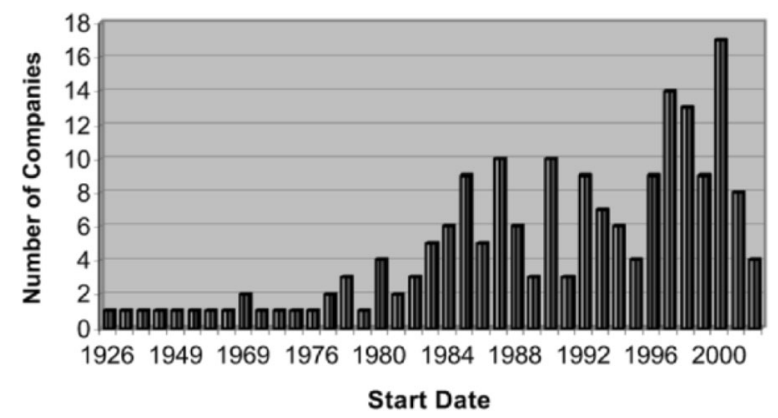

Fig. 6 The Capital Region biotechnology company start dates. Source: Feldman and Francis (2003) of national biotech patents from 2000 to 2013 and the cluster's national ranking in biotech venture capital, which amounted to about \$319 million in 2013 (FierceBiotech 2014) (Table 5).

To further underscore the density of research activity related to the production of new knowledge, we also report the number of research personnel funded through private and federal grants in the region. While these numbers are not specific to the biotech sector due to data limitations, we do see a considerable increase in research-related activity in the National Capital Region, relative to the nation since 2000 . The $50 \%$ increase in the number of principal investigators (PIs) is particularly

Table 5 Density metrics for the entrepreneurial ecosystem of WMA's biotech cluster

\begin{tabular}{|c|c|c|c|}
\hline Indicator & Biotechnology cluster metrics & WMA & USA \\
\hline \multirow[t]{7}{*}{ Density } & $\begin{array}{l}\% \text { self-employed with biotech } \\
\text { degree }\end{array}$ & $4.0 \%$ & $3.0 \%$ \\
\hline & $\%$ managers with biotech degree & $5.2 \%$ & $3.8 \%$ \\
\hline & $\begin{array}{l}\text { WMA share of US biotech patents } \\
\text { 2000-2013 }\end{array}$ & $8.9 \%$ & - \\
\hline & $\begin{array}{l}\text { Biotech venture capital national } \\
\text { ranking }\end{array}$ & 4th & - \\
\hline & $\begin{array}{l}\text { Number of research personnel } \\
\text { funded in } 2013\end{array}$ & 17,183 & 912,390 \\
\hline & $\%$ change PIs funded 2010-2013 & $50.3 \%$ & $20.3 \%$ \\
\hline & $\begin{array}{l}\% \text { change post-docs funded } 2010- \\
2013\end{array}$ & $32.1 \%$ & $26.0 \%$ \\
\hline
\end{tabular}

Source: authors' estimates. A full list of sources is in the Appendix 
relevant as it directly maps to the increase in the number of funded research projects.

Furthermore, the region's $8.9 \%$ share of all US biotech patents since 2000 is telling that the cluster is arguably highly innovative. The density indicator tells us that the National Capital Region biotech cluster outpaces the nation in the selected measures of entrepreneurial activity. The region boasts high selfemployment and managerial biotech talent as well as high concentrations of innovative research and development activity, and the capital component to help support innovation and encourage entrepreneurship.

\subsubsection{Fluidity — high and stable in- and outflows}

Entrepreneurship in the National Capital Region's biotech cluster shows considerable fluidity that is relatively stable in its net displacements. Fluidity refers to the flow of knowledge, human capital, and resources within the ecosystem. It speaks to the recombinant nature of entrepreneurship and highlights that an ecosystem's vibrancy is dependent on how freely information flows in the ecosystem and the capacity of agents to exploit it. These flows can be difficult to measure as much useful knowledge is tacit and resource networks are often informal or protected. Nonetheless, in Table 2, we estimate the net flows of workers in biotech occupations in and out of the region as well as the flow of research and development funds into the ecosystem. We also consider the National Capital Region's total job turnover in the Scientific Research and Development Services NAICS category and compare it to that of the state as a proxy for the potential for knowledge spillovers through job change. We also report the total number of high-growth firms in the cluster in healthcare-related activities and their average growth rate in 2015 as representative of the ecosystem's capacity to exploit regional resources and allocate them toward higher-productivity uses (Table 6).

The fluidity indicator tells us the cluster is fairly stable despite considerable flows in and out of the system. For instance, over 11,000 biotech workers move in and out of the National Capital Region biotech cluster annually but the net increase through migration is barely $5 \%$ of the gross flow. Furthermore, the job turnover rate for the clusters remains higher than that of the larger Maryland biotech cluster (which includes biotech activity in Baltimore, MD), suggesting more labor market activity is concentrated in the National Capital Region. Furthermore, a breakdown of total research funding by $R \& D$
Table 6 Fluidity metrics for the entrepreneurial ecosystem of WMA's biotech cluster

\begin{tabular}{|c|c|c|c|}
\hline Indicator & Biotechnology cluster metrics & WMA & $\mathrm{USA}^{\mathrm{a}}$ \\
\hline \multirow[t]{8}{*}{ Fluidity } & $\begin{array}{l}\text { Biotech population flux (net } \\
\text { migration) }\end{array}$ & 554 & - \\
\hline & $\begin{array}{l}\text { Total in-migration of biotech } \\
\text { workers }\end{array}$ & 6018 & - \\
\hline & $\begin{array}{l}\text { Job turnover in scientific R\&D } \\
\text { services in } 2013\end{array}$ & $5.0 \%$ & $3.9 \%^{\mathrm{a}}$ \\
\hline & Share of funding for basic research & $4.3 \%$ & $33.5 \%$ \\
\hline & $\begin{array}{l}\text { Share of funding for applied } \\
\text { research }\end{array}$ & $37.0 \%$ & $32.1 \%$ \\
\hline & Share of funding for development & $58.7 \%$ & $34.4 \%$ \\
\hline & $\begin{array}{l}\text { Number of high-growth firms in } \\
\text { health in } 2015\end{array}$ & 7 & - \\
\hline & $\begin{array}{l}\text { Average growth rate of Inc. } 5000 \\
\text { firms in health }\end{array}$ & $655 \%$ & - \\
\hline
\end{tabular}

Source: authors' estimates. A full list of sources is in the Appendix

${ }^{\text {a }}$ Comparative job turnover rate is shown for the state of Maryland

activity to the cluster demonstrates the region has a competitive advantage in attracting development-related funding, as compared to basic research or applied research. This reveals a particular feature of the regional cluster worth investigating further. The National Capital Region also has seven high-growth firms in the healthcare sector in 2015 that are growing at an average pace of $655 \%$. Each of the seven firms reports at least $\$ 2$ million in revenues. The fastest growing of these ranks 207th among healthcare-related high-growth firms in the nation. Arguably, the National Capital Region biotech cluster has room to improve on this metric.

\subsubsection{Connectivity—strong established networks}

The connectivity indicator reveals that the National Capital Region biotech cluster has strong and established networks that support entrepreneurial activity. It measures the prevalence of networks that allow for more efficient channeling of resources for entrepreneurial exploits. It is measured as the connections between programs and resources, and in our analysis, we use the regional share of internationally recognized "star" scientists and researchers. We also include estimates for the amount of funding regional universities receive from foreign sources as well as for biotechrelated research. As biotech research is globally connected, a relative increase in regional activity can be used as a proxy measure for the region's importance in international biotech research networks. Finally, we also include another 
Table 7 Connectivity metrics for the entrepreneurial ecosystem of WMA's biotech cluster

\begin{tabular}{|c|c|c|c|}
\hline Indicator & $\begin{array}{l}\text { Biotechnology cluster } \\
\text { metrics }\end{array}$ & WMA & USA \\
\hline \multirow[t]{8}{*}{ Connectivity } & $\begin{array}{l}\text { Total R\&D funding } \\
\text { 2010-2013 } \\
\text { (thousands \$) }\end{array}$ & $\$ 8,940,462$ & $\$ 70,165,128$ \\
\hline & $\begin{array}{l}\text { R\&D university } \\
\text { funding } 2013 \\
\text { (thousands \$) }\end{array}$ & $\$ 1,295,311$ & $\$ 67,041,154$ \\
\hline & $\begin{array}{l}\% \text { change in foreign } \\
\text { funding } 2010-2013\end{array}$ & $19.9 \%$ & $53.0 \%$ \\
\hline & $\begin{array}{l}\% \text { change medical and } \\
\text { clinical trial funds } \\
2010-2013\end{array}$ & $-6.3 \%$ & $7.1 \%$ \\
\hline & $\begin{array}{l}\% \text { change in biomed } \\
\text { and life-sci funds } \\
2010-2013\end{array}$ & $18.1 \%$ & $7.8 \%$ \\
\hline & $\begin{array}{l}\text { Star biotech scientists } \\
\text { and researchers }\end{array}$ & 169 & 952 \\
\hline & $\begin{array}{l}\text { WMA share of US } \\
\text { biotech researchers }\end{array}$ & $17.8 \%$ & - \\
\hline & $\begin{array}{c}\text { Nationally competitive } \\
\text { biotech incubators }\end{array}$ & \multicolumn{2}{|c|}{$\begin{array}{l}\text { Alexandria LaunchLabs } \\
\text { Biohealth Innovation } \\
\text { Prince William Science }\end{array}$} \\
\hline
\end{tabular}

Source: authors' estimates. A full list of sources is in the Appendix

qualitative estimate of the number of biotech incubators with some national activity.

As Table 7 reports, the biotech cluster in the National Capital Region receives nearly $\$ 1.3$ billion in universitybased $R \& D$ funding or nearly $2 \%$ of total universitybased R\&D funding in the country. This proportion is relatively small, but considering the cluster also receives $12 \%$ of the national $\mathrm{R} \& \mathrm{D}$ funding, the numbers provide some idea of the region's reliance on federal-funded $R \& D$ centers. Yet, this reliance on federal $R \& D$ centers may be decreasing relative to university-based support. Since 2010, regional universities have seen a significant increase in foreign funding as well as funding specific to biomedical and life science research. A 6.3\% decline in funding support for clinical and medical trails may also suggest a shift in the type of research activity the regional biotech cluster specializes in. Another key R\&D-related strength of the region's biotech knowledge flows is indicated by the fact that nearly $18 \%$ of leading US biotech scientists work for institutions in the National Capital Region. The region also has also attracted many biotech incubators that help entrepreneurs bring innovations to market, at least three of which have some national recognition based on articles in industry trade journals.

\subsubsection{Diversity — high in skills but low in sectoral diversity}

The final indicator of diversity demonstrates the National Capital Region biotech cluster's economic complexity. Diversity is an essential driver for opportunity generation and is an indicator for how well an ecosystem engages all its entrepreneurial potential. Vibrant ecosystems utilize their available resources efficiently and allow for solutions to problems to arise from both inside and outside of the ecosystem. Keeping this in mind, our metrics for the diversity indicator include the percent of women and foreign-born immigrants self-employed in the biotech cluster. Additionally, we also estimate the distribution of employment across the different biotech NAICS codes as a measure for cluster diversification (Table 8).

The diversity metrics reported in Table 4 suggest that the National Capital Region biotech cluster is significantly more representative of female and immigrant entrepreneurs compared to the nation, and it also attracts a greater share of biotech workers from abroad. However, the indicator also reinforces that the region's biotech cluster is much more specialized relative to the nation, the specialization being driven by concentrations in the "Research and Development in Biotechnology" NAICS sector.

Although the National Capital Region biotech cluster had reached maturity in the conservation phase by the early 2000s, Fig. 7 shows how the cluster entered a new "Cluster Reorientation" phase (Martin and Sunley 2011) whereby firms and industries within the cluster reoriented their technical specialization to represent a newer industry structure.

Table 8 Diversity metrics for the entrepreneurial ecosystem of WMA's biotech cluster

\begin{tabular}{llll}
\hline Indicator & Biotechnology cluster metrics & $\begin{array}{l}\text { WMA } \\
(\%)\end{array}$ & $\begin{array}{l}\text { USA } \\
(\%)\end{array}$ \\
\hline Diversity & $\begin{array}{l}\text { Percent women self-employed in } \\
\text { biotech } \\
\text { Percent immigrants self-employed in } \\
\text { biotech }\end{array}$ & 62 & 37 \\
$\quad \begin{array}{l}\text { Immigrant share of biotech } \\
\text { workforce } \\
\text { Employment share of the largest } \\
\quad \text { NAICS in cluster }\end{array}$ & 34.0 & 29.5 & 30.6 \\
\hline
\end{tabular}

Source: authors' estimate. A full list of sources is in the Appendix 
Fig. 7 Growth of the Capital Region biotech cluster relative to the USA, base year 1990. Source: Quarterly Census of Employment and Wages 1990-2015

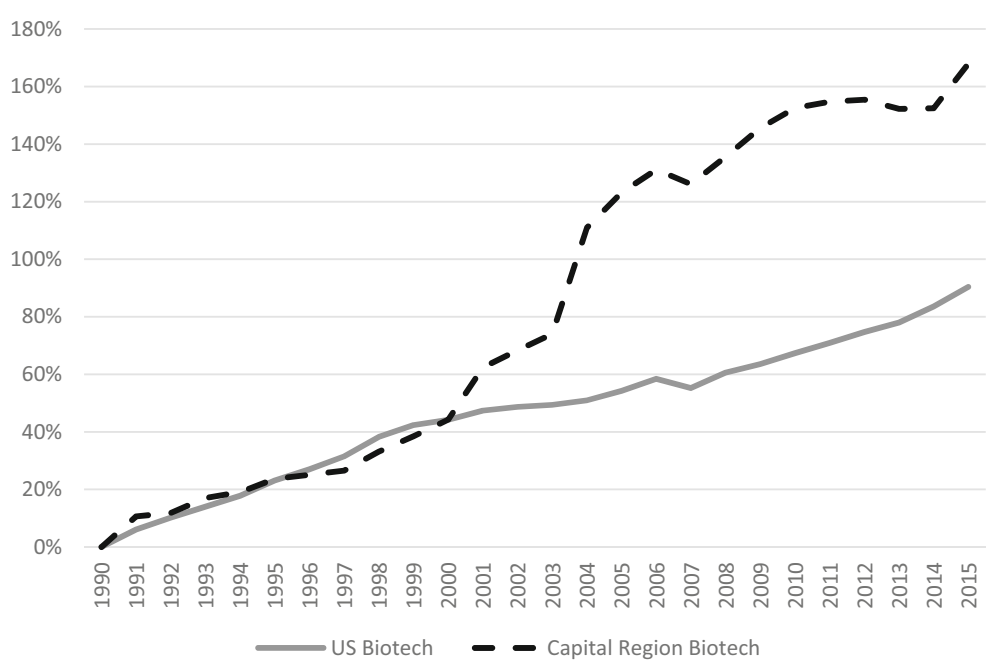

As seen in Fig. 8, this reorientation can be seen in the relatively stronger growth in non-research-oriented activities and an increasing share of biotech and biotechrelated manufacturing and sales-related activity.

5.5 Resilience and cross-scale interactions of the National Capital Region biotech cluster

The metrics for each of the four indicators discussed above reveal that the biotechnology cluster in the National Capital Region outpaces the national average in almost all measures. The cluster has a strong base for entrepreneurship and innovation and is resourceful in attracting the capital and knowledge resources required to maintain its competitive advantage. Yet, a few salient characteristics unique to this cluster are also revealed. For instance, the National Capital Region biotech cluster is heavily concentrated in R\&D activity as compared to manufacturing. It also retains strong connections to the federal government that directly influence the research activity in the cluster. Additionally, while the cluster attracts significant venture capital, it still lags other biotech clusters in terms of incubators and private sector entrepreneurial networks. This begs the following questions: Is the development of the biotech cluster sustainable? Can a federal government sequester in healthcare shock the system? How resilient is the National Capital Region biotech sector?

Using insights from Holling and Gunderson (2002), we also assessed the distribution of establishments in the
Fig. 8 Consolidation of Capital Region's biotech cluster, base year 1990. Source: Quarterly Census of Employment and Wages 1990-2015

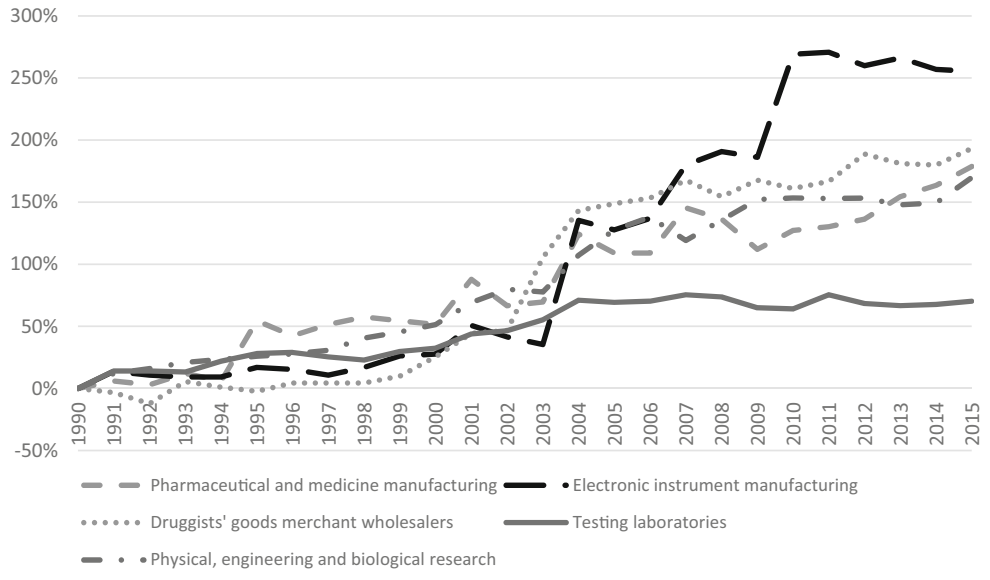


Fig. 9 Biotech establishments by size in the WMA from 2004 to

2013. Establishments with $>500$ employees plotted on secondary access. Values imputed for

NAICS 541711: R\&D in biotechnology prior to 2008 . Source: authors' calculations of data from the County Business Patterns 2004-2013

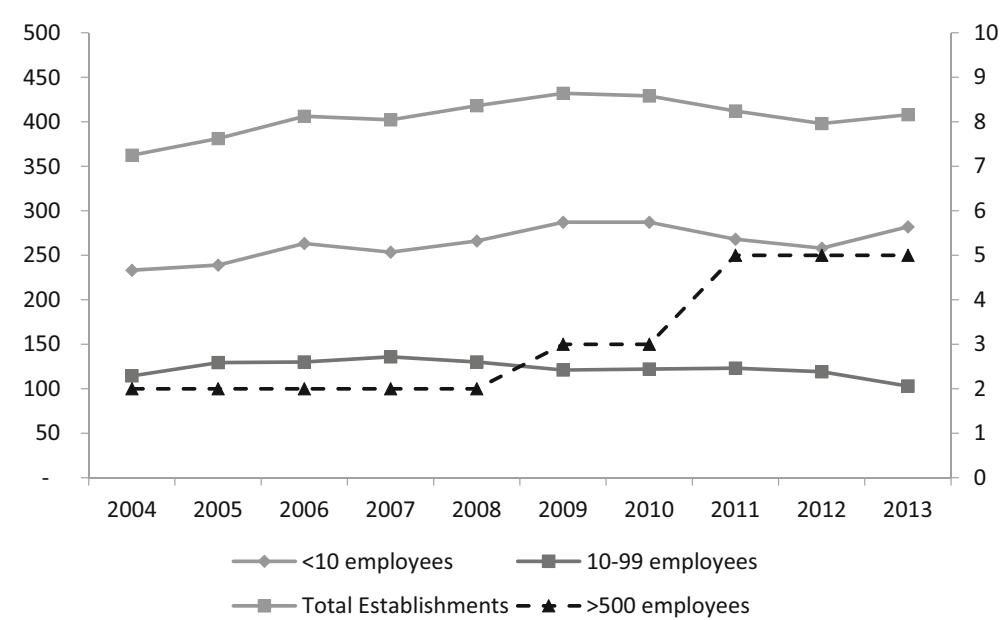

National Capital Region biotech cluster by size from 2004 to 2013. The growth in the number of small establishments with less than 10 employees and those with between 10 and 99 employees is shown in the left axis of Fig. 9. The right axis shows the growth trajectory of large firms employing over 500 workers. It is worth noting that overall establishment growth in the sector is not only driven by the increase in the number of small, likely entrepreneurial firms, but also there is a recent increase in the presence of large establishments as well. These large firms concentrate significant economic activity, fuel spin-offs, acquire promising entrepreneurial firms, and strengthen networks that reinforce the structure of the entrepreneurial ecosystem.

This cross-scale analysis of the ecosystem can provide some insight in developing policy-relevant adaptive models of the entrepreneurial ecosystem. Where the federal institutes and FFRDCs formed the large-scale networks ${ }^{19}$ in the early development of the regional biotech ecosystem, the past few years have seen an increase in the influence of large firms in the region. The entry of large establishments may signal greater levels of M\&A activity and the increase in venture capital funds flooding into the region. This trend is potentially indicative of increased private sector independence in the region's biotech cluster, yielding an added measure of resilience to the ecosystem.

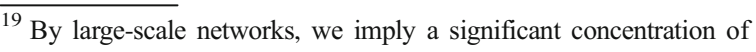
resources and influence over the ecosystem.
}

Our analysis reveals that the biotech entrepreneurial ecosystem in the National Capital Region is in a conservation phase of its life cycle where stored nutrients and energy are at their peak and the system has achieved a high level of interconnectedness. It is a result of a long period of growth in the ecosystem that has culminated in strong and complex interdependencies. Yet, the cluster's structure is far from static. An increasing regional presence of large biotech firms in the past 5 years, a highly active and diverse start-up sector, underlying shifts in R\&D activity, along with increasing M\&A activity, all coupled with declines in regional public funding for medical and clinical trials are suggestive of an increasing influence of private sector actors. For a cluster that emerged and grew in the shadow of the federal government, these structural changes may present opportunities for diversification of the National Capital Region's economic base, away from an over-reliance on the federal government.

\section{Conclusion}

In this paper, we have sought to advance understanding of the role of entrepreneurship in developing essential capabilities and networks that drive the sustainable development of regions. Focusing on the case of the biotechnology cluster in the National Capital Region, we have presented an empirical framework that can be utilized for (1) assessing the vibrancy of a regional entrepreneurial ecosystem and (2) using that assessment 
to map the adaptive life cycle of an industry cluster developing within the ecosystem.

We adopted a conceptualization of the regional biotechnology entrepreneurial ecosystem similar in spirit to Sussan and Acs (2017), whereby the ecosystem represents the higher-level infrastructure that enables interactions between the entrepreneurial agents and institutions in the industrial sector. In so doing, we identified clusters as bounded by an industry, whereas entrepreneurial ecosystems cut across industries. Entrepreneurial ecosystems focus on the environment surrounding entrepreneurswith entrepreneurs and entrepreneurship clearly at the center.

In our analysis specific to the National Capital Region's biotechnology cluster, we concluded that the cluster is, presently, in the conservation phase of its life cycle: It demonstrates high levels of entrepreneurial vibrancy that spans networks across different levels and scales of the ecosystem. By focusing on how each of the metrics considered in this paper relates to the overall structure of entrepreneurial activity, we were able to identify potential areas of change in the ecosystem. A key finding was that although the history of the region's biotechnology cluster showed a high reliance on the federal government, recent shifts in R\&D activity and the broadening of private sector networks identify likely pathways in which the cluster may diversify away from a specialized dependence on government activity. Our analysis highlights that, in an entrepreneurial ecosystem framework, the best opportunities for policymaking arguably arise neither from correcting conventionally defined market failures nor from a singular focus on context-independent "best practices." Instead, the best opportunities for policy-making may arise from understanding, and capitalizing upon, evolutionary transitions within regional entrepreneurial ecosystems and subsidiary industry clusters.

For example, while our study reveals that the biotech cluster in the National Capital Region's entrepreneurial ecosystem is in the conservation phase of its life cycle, the cluster's structure is not in stasis. An increasing regional presence of large biotech firms in the past 5 years, a highly active and diverse start-up sector, increasing merger and acquisition activity, and declines in regional public funding for medical and clinical trials are all suggestive of an increasing influence of private sector actors. For a cluster that emerged and grew in the shadow of the federal government, these structural changes may represent valid opportunities for diversification of economic activity while building on the cluster's competitive advantages. Implications of such an interpretation can help regional policymakers consider new options for facilitating the evolution of the National Capital Region's economy toward increasing diversification-with diminished dependence on the federal government as an integral part of that process.

Beyond the specific application to the National Capital Region, this paper constitutes an initial attempt at mapping the adaptive life cycle of an industry cluster within the context of the broader evolution of the regional entrepreneurial ecosystem. We know that, at different phases in the evolution of a biological ecosystem, conditions will prevail that present advantages for some species, but challenges for others. Understanding this, we contextualize various entrepreneurial features of the biotechnology cluster with regard to the evolutionary dynamics of the regional economy as a whole. Accordingly, our framework serves as a model for qualitatively assessing the adaptive life cycle dynamics of entrepreneurial ecosystems, enabling economic growth in industry clusters.

Even more broadly, the analysis in this paperand the contributions to this special issue of Small Business Economics as a whole-raise interesting questions regarding the extent to which regional economies are subject to "management," as normally understood. To the extent that regional economies are-as Alfred Marshall conjectured a century ago - truly biological in nature, then the role of policymakers in "managing" regional economies is much more like that of an ecologist than an engineer. Writing on the basis of personal experience as a cofounder of UCSD CONNECT, which contributed significantly to the emergence of a biotechnology cluster in San Diego, CA, in the 1980s, Mary Walshok writes:

The scholarly literature has given an enormous amount of attention to such things as university technology transfer and IP policies, business-planning competitions and entrepreneurship education for undergraduates, and the complex financing needs of technology- 
based startups, especially for proof of concept and clinical applications development. Less attention has been focused on the importance of the larger ecosystem in supporting emerging entrepreneurs on their journey to convert a promising idea or technology into a viable business that can create jobs for the region, as well as revenue that contributes to the local tax base and, eventually, to philanthropy. The San Diego experience and the catalytic role played by CONNECT represent an interesting case of an organization that focused from day one on building an ecosystem that broadly supported innovation and entrepreneurship, and not just a narrow set of issues related to individual entrepreneurs. ${ }^{20}$

Success for CONNECT in San Diego depended critically on approaching the problem from the outset as one of fostering the development of an industry by nurturing the broader entrepreneurial ecosystem.

Within a regional entrepreneurial ecosystem, the outcome of any intervention will depend critically on the stage of evolution of the ecosystem and will have differential impacts on all of the industries (which is to say, species) resident in the ecosystem. These differential impacts of policy interventions will go well beyond conventional, static breakdowns between "winners" and "losers," and instead open up domains of inquiry that encompass the adaptive life cycles of all the interconnected and interdependent industry clusters that comprise the ecosystem. As a consequence, policymakers working at the regional level can benefit greatly from tools - broadly in the spirit of those proposed in this paper - that allow for regular monitoring and assessment of the vitality of the entrepreneurial ecosystem, and the life cycle stage of the industry clusters comprising the ecosystem. ${ }^{21}$

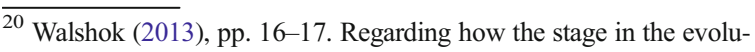
tion of the regional economy affected the conceptualization of CONNECT, Walshok (2013) adds (p. 10): “[A]t San Diego's moment of crisis, when large employers such as General Dynamics were beginning to downsize, a national furniture manufacturer was leaving, and efforts to attract $R \& D$ consortia had failed, regional leaders shifted their attention to growing more local enterprises that would draw on the technology applications emerging from the basic research being done on the Torrey Pines Mesa."

${ }^{21}$ See Auerswald (2015) for discussion of a program of action for policymakers consistent with the analysis in this paper.
}

\section{Appendix}

Table 9 NAICS codes used to define the biotechnology cluster

Biotechnology cluster NAICS definition

NAICS Description

32519 Other basic organic chemical manufacturing

3253 Pesticide, fertilizer, and other agricultural chemical manufacturing

3254 Pharmaceutical and medicine manufacturing

334510 Electromedical and electrotherapeutic apparatus manufacturing

334516 Analytical laboratory instrument manufacturing

4242 Drugs and druggists' sundries merchant wholesalers

54138 Testing laboratories

541711 Physical, engineering, and biological research

Table 10 Biotechnology-related degrees or fields of study

Field of degree (American community survey)

2402 Biological engineering

2404 Biomedical engineering

2405 Chemical engineering

$2410 \quad$ Environmental engineering

3600 Biology

3601 Biochemical sciences

3602 Botany

3603 Molecular biology

3604 Ecology

3605 Genetics

3606 Microbiology

3607 Pharmacology

3608 Physiology

3609 Zoology

$3611 \quad$ Neuroscience

3699 Miscellaneous biology

4006 Cognitive science and biopsychology

5003 Chemistry

5102 Nuclear, industrial radiology, and biological technologies

6105 Medical technology technicians

6108 Pharmacy pharmaceutical sciences and administration 
Table 11 Biotechnology patent classes

\section{Class Class title}

424 Drug, bio-affecting and body-treating compositions (includes Class 514)

435 Chemistry: molecular biology and microbiology

128 Surgery (includes Class 600)

532 Organic compounds (includes Classes 532-570)

606 Surgery (instruments)

520 Synthetic resins or natural rubbers (includes Classes 520-528)

604 Surgery (medicators and receptors)

607 Surgery: light, thermal, and electrical application

623 Prosthesis (i.e., artificial body members), parts thereof, or aids and accessories

800 Multicellular living organisms and unmodified parts thereof and related processes

530 Chemistry: natural resins or derivatives; peptides or proteins; lignins or reaction products thereof

430 Radiation imagery chemistry: process, composition, or product thereof

436 Chemistry: analytical and immunological testing

378 X-ray or gamma ray systems or devices

119 Animal husbandry

351 Optics: eye examining, vision testing, and correcting

433 Dentistry

585 Chemistry of hydrocarbon compounds

602 Surgery: splint, brace, or bandage

208 Mineral oils: processes and products

$47 \quad$ Plant husbandry

601 Surgery: kinesitherapy

506 Combinatorial chemistry technology: method, library, apparatus

$44 \quad$ Fuel and related compositions

504 Plant protecting and regulating compositions

376 Induced nuclear reactions: processes, systems, and elements

111 Planting

516 Colloid systems and wetting agents, subcombinations thereof, processes of making, stabilizing, breaking, or inhibiting

518 Chemistry: Fischer-Tropsch processes; or purification or recovery of products thereof

494 Imperforate bowl: centrifugal separators

71 Chemistry: fertilizers

127 Sugar, starch, and carbohydrates

23 Chemistry: physical processes

196 Mineral oils: apparatus

260 Chemistry of carbon compounds 
Table 12 List of all entrepreneurial ecosystem metrics and their sources

\begin{tabular}{|c|c|c|}
\hline Indicator & Biotechnology cluster metrics & Source \\
\hline \multirow[t]{7}{*}{ Density } & Percent self-employed with biotech degree & ACS 2013 5-year estimates \\
\hline & Percent managers with biotech degree & ACS 2013 5-year estimates \\
\hline & Regional share of US biotech patents 2000-2013 & USPTO database \\
\hline & Biotech venture capital national ranking & fiercebiotech.com \\
\hline & Research personnel funded in 2013 & National Science Foundation \\
\hline & $\%$ change PIs funded 2010-2013 & National Science Foundation \\
\hline & $\%$ change post-docs funded $2010-2013$ & National Science Foundation \\
\hline \multirow[t]{8}{*}{ Fluidity } & Biotech population flux (net migration) & ACS 2013 5-year estimates \\
\hline & In-migration of biotech workers & ACS 2013 5-year estimates \\
\hline & Job turnover in scientific R\&D services in 2013 & Quarterly Workforce Indicators \\
\hline & Share of funding for basic research & National Science Foundation \\
\hline & Share of funding for applied research & National Science Foundation \\
\hline & Share of funding for development & National Science Foundation \\
\hline & Number of high-growth firms & Inc. 50002015 \\
\hline & Average growth rate of Inc. 5000 firms in health & Inc. 50002015 \\
\hline \multirow[t]{8}{*}{ Connectivity } & Total R\&D federal funding 2010-2013 & National Science Foundation \\
\hline & R\&D university funding 2013 & National Science Foundation \\
\hline & $\%$ change foreign funding $2010-2013$ & National Science Foundation \\
\hline & $\%$ change medical and clinical trial funding 2010-2013 & National Science Foundation \\
\hline & $\%$ change in biomed and life-sci funds 2010-2013 & National Science Foundation \\
\hline & Star scientists & Web of Science \\
\hline & Capital Region share of US biotech researchers & Web of Science \\
\hline & Biotech incubators & GEN, Biospace, FierceBiotech \\
\hline \multirow[t]{4}{*}{ Diversity } & Percent women self-employed in biotech & ACS 2013 5-year estimates \\
\hline & Percent immigrants self-employed in biotech & ACS 2013 5-year estimates \\
\hline & Immigrant share of biotech workforce & ACS 2013 5-year estimates \\
\hline & Employment share of the largest NAICS in cluster & County Business Patterns 2013 \\
\hline
\end{tabular}

\section{References}

Acs, Z. J., Estrin, S., Mickziewicz, T., \& Szerb, L. (2014). The continued search for the solow residual: the role of national entrepreneurial ecosystems. IZA Discussion Paper No. 8652, 2014 November. Institute for the study of Labor.

Audretsch, D. B. (2001). The role of small firms in U.S. biotechnology clusters. Small Business Economics, 3-15.

Auerswald, P. E. (2015). Enabling entrepreneurial ecosystems. In D. Audretsch, A. Link, \& M. Walshok, Oxford handbook of local competitiveness. New York, NY: Oxford University Press.

Auerswald, P. E. (2017). The code economy: a forty-thousand year history. New York, NY: Oxford University Press.
Auerswald, P. E., \& Branscomb, L. M. (2003). Valleys of death and Darwinian seas: financing the invention to innovation transition in the United States. Journal of Technology Transfer, 227-239.

Auerswald, P. E., \& Dani, L. M. (2017). Economic ecosystems. In G. Clark, M. Feldman, M. Gertler, \& D. Wojcik, The new Oxford handbook of economic geography. Oxford: Oxford University Press, forthcoming.

Auerswald, P. E., Kauffman, S., Lobo, J., \& Shell, K. (2000). The production recipes approach to modeling technological innovation: an application to learning by doing. Journal of Economic Dynamics and Control, 24, 389-450.

Auerswald, P., Branscomb, L., Gorman, S., Kulkarni, R., \& Schintler, L. (2007). Placing innovation: a geographic information systems (GIS) approach to identifying emergent technological activity. Gaithersburg, MD: National Institute of Standards and Technology, US Department of Commerce. 
Bengtsson, J., Nilsson, S. G., Franc, A., \& Menozzidi, P. (2000). Biodiversity, disturbances, ecosystem function and management of European forests. Forest Ecology and Management, 132(1), 39-50.

Biotechnology Industry Organization. (2012). Testimony of the biotechnology industry organization on competition and intellectual property law and policy in the knowledge E-based economy. Berkeley, CA: Competition Policy Center.

Branscomb, L. M., \& Auerswald, P. E. (2001). Taking technical risks: how innovators, managers, and investors manage high-tech risks. Cambridge, MA: MIT Press.

Carlson, R. (2016). Estimating the biotech sector's contribution to the US economy. Nature Biotechnology, 247-255.

Casper, S. (2007). How do technology clusters emerge and become sustainable?: social network formation and inter-firm mobility within the San Diego biotechnology cluster. Research Policy, 438-455.

Cooke, P. (2002). Regional innovation systems: general findings and some new evidence from biotechnology clusters. The Journal of Technology Transfer, 133-145.

Feldman, M. P., \& Francis, J. L. (2003). Fortune favors the prepared region: the case of entrepreneurship and the capitol region biotechnology cluster. European Planning Studies, 11(7), 765-788.

Feldman, M., Francis, J., \& Bercovitz, J. (2005). Creating a cluster while building a firm: entrepreneurs and the formation of industrial clusters. Regional Studies, 129-141.

FierceBiotech. (2014). The top 15 cities for biotech venture funding. Retrieved 11 20, 2015, from FierceBiotech: The biotech industry's daily monitor: http://www.fiercebiotech. com/story/top-15-cities-biotech-venture-funding/2014-03-06

Fuller, S. S. (2016). The roadmap for the Washington region's future economy. 24th Annual Economic Conference. Washington, D.C.: Center for Regional Analysis.

Gavrilets, S. (1999). A dynamical theory of speciation on holey adaptive landscapes. The American Naturalist, 1-22.

Gavrilets, S. (2004). Fitness landscapes and the origin of species. Princeton: Princeton University Press.

Genus, A., \& Coles, A.-M. (2008). Rethinking the multi-level perspective of technological transitions. Research Policy, $1436-1445$.

Hecker, D. E. (2005). High-technology employment: a NAICSbased update. Monthly Labor Review, 57-72.

Holling, C. S. (2001). Understanding the complexity of economic, ecological, and social systems. Ecosystems, 390-405.

Holling, C. S., \& Gunderson, L. H. (2002). Panarchy: understanding transformations in human and social systems. Washington, D.C. : Island Press.
Holling, C. S., Gunderson, L. H., \& Light, S. (1995). Barriers and bridges to the renewal of ecosystems. New York: Columbia University Press.

Isenberg, D. J. (2010a). How to start an entrepreneurial revolution. Harvard Business Review, 88(6), 40-50.

Isenberg, D. J. (2010b). Can policy makers create an ecosystem for entrepreneurship? The Economist.

Marshall, A. (1920). Principles of economics. London: Macmillan.

Martin, R., \& Sunley, P. (2011). Conceptualizing cluster evolution: beyond the life cycle model? Regional Studies, 1299-1318.

Nelson, R. R., \& Winter, S. G. (1982). An evolutional theory of economic change. Cambridge, MA: Harvard University Press.

Rosenthal, S. S., \& Strange, W. C. (2001). The determinants of agglomeration. Journal of Urban Economics, 191-229.

Schumpeter, J. A. (1951). The theory of economic development. An inquiry into profits, capital, credit, interest and the business cycle. Cambridge, MA: Harvard University Press.

Spencer, H. (1857). Progress: its law and causes. The Westminster Review.

Stangler, D., \& Bell-Masterson, J. (2015). Measuring an entrepreneurial ecosystem. Kansas City, MO: Kauffman Foundation Research Series on City, Metro, and Regional Entrepreneurship.

Sussan, F., \& Acs, Z. J. (2017). The digital entrepreneurial economy. Small Business Economics.

Terjesen, S., Acs, Z. J., Audretsch, D. B., Hechavarria, D., Stam, E., \& White, R. (2017). Entrepreneurial ecosystems: a literature review. University of Tampa Working Paper.

Valdez, J. (1988). The entrepreneurial ecosystem: toward a theory of new business formation. Small Business Institute Director's Association. SBIDA.

Van De Ven, H. (1993). The development of an infrastructure for entrepreneurship. Journal of Business Venturing, 211-230.

Wallsten, S. J. (2001). An empirical test of geographic knowledge spillovers using geographic information systems and firmlevel data. Regional Science and Urban Economics, 571599.

Walshok, M. (2013). A systemic approach to accelerating entrepreneurship. Innovations: Technology, Governance, Globalization, 8(3/4), 7-17.

Weitzman, M. (1970b). Optimal growth with economies of scale in the creation of overhead capital. Review of Economic Studies, 555-570.

Weitzman, M. (1998). Recombinant growth. Quarterly Journal of Economics, 331-360.

Weitzman, M. L. (1970a). Soviet postwar economic growth and capital-labor substitution. American Economic Review, 676692. 